\title{
Leukocyte recruitment in preterm and term infants
}

Katinka Karenberg ${ }^{1}$, Hannes Hudalla ${ }^{1,2}$ and David Frommhold ${ }^{1 *}$ (D)

\begin{abstract}
Impaired cellular innate immune defense accounts for susceptibility to sepsis and its high morbidity and mortality in preterm infants. Leukocyte recruitment is an integral part of the cellular immune response and follows a welldefined cascade of events from rolling of leukocytes along the endothelium to firm adhesion and finally transmigration which is concerted by a variety of adhesion molecules. Recent analytical advances such as fetal intravital microscopy have granted new insights into ontogenetic regulation and maturation of fetal immune cell recruitment. Understanding the fetal innate immune system is essential for targeted prevention and therapy of premature infants with severe infections or disorders of the immune system. This review gives an overview of the basic principles of leukocyte recruitment, particularly neutrophil trafficking, and its development during early life and highlights technical limitations to our current knowledge.
\end{abstract}

Keywords: Leukocyte recruitment, Preterm, Newborn, Fetus, Rolling, Adhesion, Transmigration, Neutrophil, Sepsis, Innate immunity

\section{Introduction}

Prematurity is the most prominent risk factor for neonatal diseases and death [1]. Despite medical progress in newborn medicine, mortality remains high since the number of very low birth weight infants $(\leq 1500 \mathrm{~g})$ increases globally [2-4]. Especially among very immature infants, infection and sepsis are still the leading causes for mortality and morbidity $[2,5]$. This may in part be explained by the immaturity of the innate immune system, which preterm infants ( $<37$ weeks of gestation) heavily rely on as the adaptive immune system is not yet formed [6]. Intrauterine fetal immunosuppression plays a key role in preventing excessive adverse immune reactions at the feto-maternal placental border. Yet, this beneficial intrauterine feature proves disadvantageous in preterm infants lacking maternal immune protection while being exposed to high levels of pathogens. Up to $60 \%$ of extremely premature infants $(<28$ weeks of gestation and/or $<1000 \mathrm{~g}$ birth weight) may suffer from bacterial sepsis in contrast to less than $5 \%$ of late preterm and term neonates [7], which indicates that the immune response evolves

\footnotetext{
* Correspondence: David.Frommhold@med.uni-heidelberg.de ${ }^{1}$ Department of Neonatology, University Children's Hospital, Im Neuenheimer Feld 430, 69120 Heidelberg, Germany

Full list of author information is available at the end of the article
}

throughout gestation. The mortality risk sharply decreases with each additional week of gestation and rise in birth weight [4]. Researchers are only beginning to understand the complex ontogenetically regulated maturation of the fetal immune system and how to alter or support this transition.

The impaired function of the premature immune system has multiple causes: lack of immunoglobulins [8] and antimicrobial peptides [9], low levels of circulating complement factors, and lack in total number and maturation of immune cells [10]. Neutropenia and immature neutrophil trafficking partially account for the high susceptibility to opportunistic and bacterial infections [11]. Despite increasing evidence for a highly complex role of leukocytes in both innate and adaptive immunity, this short review focuses on the ontogenetic development of leukocyte recruitment, in particular polymorphonuclear neutrophils (PMN), as one key component of innate immunity in preterm neonates.

\section{Leukocyte recruitment}

Leukocyte recruitment is an integral part of the cellular immune response and follows a defined cascade of events [12]. After recognition of invading pathogens, leukocytes are stimulated with the primary purpose of 
eliminating the inflammatory source. This multistep process starts with the capture of circulating leukocytes from the blood stream, mostly in postcapillary venules in close proximity to inflamed tissue. A simplified version of the leukocyte recruitment cascade exemplified for neutrophils is displayed in Fig. 1 (developmental aspects are indicated by footnotes and discussed in the next chapter).

The initial step of leukocyte rolling is mediated by selectins, which bind to their respective ligands such as P-selectin glycoprotein ligand 1 (PSGL-1), CD44, or E-selectin ligand 1 (ESL-1) $[13,14]$. The three known members of the selectin family are L-, P-, and E-selectin. After activation of endothelial cells, adhesion molecule upregulation drives leukocyte adhesion to the vessel wall. The interaction of selectins and chemokines with their respective receptors triggers integrin activation (e.g. macrophage antigen 1 (Mac-1), lymphocyte function-associated antigen 1 (LFA-1)) which in turn bind to their endothelial ligands (intercellular adhesion molecule 1 (ICAM-1), vascular cell adhesion molecule 1 (VCAM-1), receptor for advanced glycation endproducts (RAGE)) [15] leading to leukocyte deceleration and finally adhesion [16]. The firm leukocyte adhesion is crucially mediated by tight bonds between integrins and their ligands balanced by permanent inside-out integrin signaling (intracellular signaling activates integrin on cell-surface) and outside-in integrin signaling (ligand-induced activation of intracellular signaling pathways) [12, 17-19]. Subsequently, spreading is induced by integrin-mediated rearrangement of actin cytoskeleton followed by crawling along the endothelium in order to find a designated site to transmigrate from vessel into inflamed tissue [20, 21]. Intravascular chemokine gradients guide leukocytes to sites of damage [22]. Transmigration depends on many different factors like distribution and density of integrin ligands, chemoattractants, and other cytokines as well as adhesive ligands [23]. Two different routes of transmigration are known: paracellular at endothelial borders (70-90 \%) [14] or transcellular. After transendothelial cell migration (TEM), leukocytes display an altered phenotype, enhanced survival, and enhanced ability to eliminate pathogens [13]. For sufficient diapedesis, a weakening of endothelial junctions and an increase in cytosolic free calcium is required [24]. The site of transmigration may depend on the condition of junctions, so leukocytes are likely to take the nearest route with least resistance in an acceptable range. The key molecules involved in the leukocyte recruitment cascade are summarized in Table 1 based on a recent review by Vestweber [25].

\section{Maturation of fetal leukocyte recruitment}

Understanding the fetal innate immune system is essential for targeted prevention and therapy of premature infants with severe infections or disorders of the immune system. The high vulnerability of preterm neonates to suffer from severe infections and sepsis can partially be attributed to impaired leukocyte recruitment early during fetal life [11]. The observation of reduced fetal leukocyte trafficking and chemotaxis is mainly explained by diminished expression of leukocyte adhesion molecules and production of cytokines at this developmental

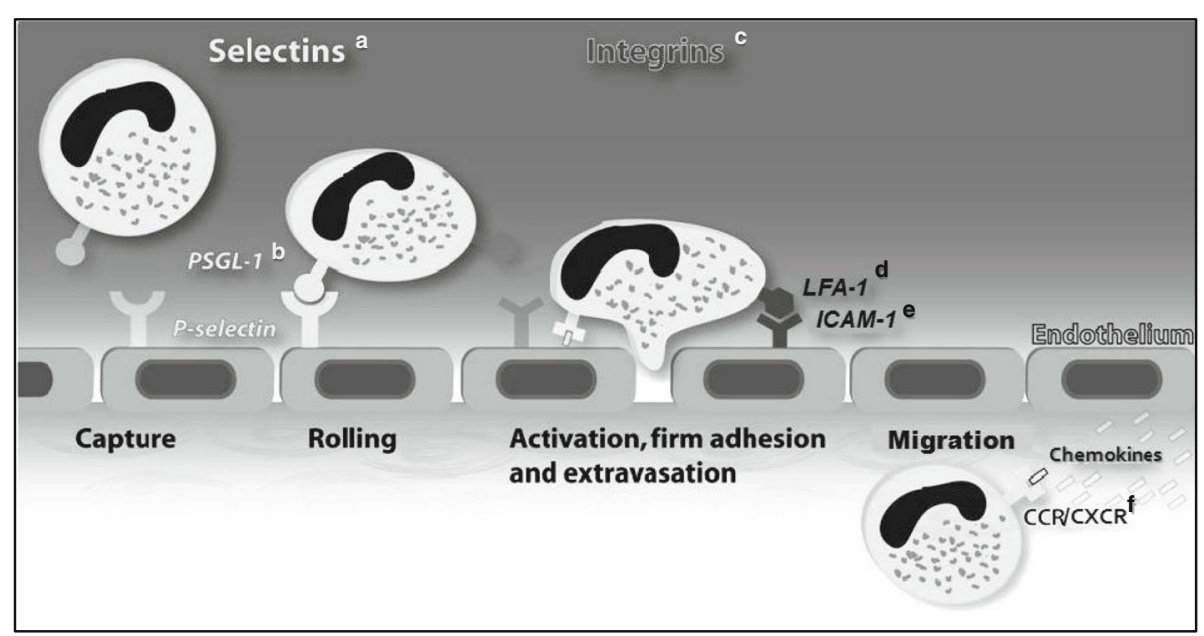

Fig. 1 Leukocyte recruitment cascade. The multistep recruitment cascade is illustrated using the example of a neutrophil. It starts with the capture of circulating neutrophils from the blood stream, followed by selectin-dependent rolling and chemokine- and integrin-dependent adhesion. After extravasation, the neutrophil follows chemokine gradients through the tissue to the point of damage/inflammation. Developmental alterations of adhesion molecule expression are indicated by footnotes as follows (fetal/premature levels were compared to those of adults): (a) Lselectin - reduced [26, 33, 37, 45, 46] and unchanged [47], E-selectin - reduced [29, 31, 38], P-selectin - reduced [29, 34, 38, 39]; (b) PSGL-1 - reduced $[29,31,36] ;$ (c) Mac-1 - reduced [26, 31, 36], unchanged [30, 33], and increased [37]; (d) LFA-1 - reduced [26, 45] and unchanged [30, 31, 36, 37]; (e) ICAM-1 - reduced [29, 31, 38]; (f) CXCR2 - unchanged [31] 
Table 1 Leukocyte adhesion molecules

\begin{tabular}{|c|c|c|c|}
\hline $\begin{array}{l}\text { Endothelial adhesion } \\
\text { molecule }\end{array}$ & $\begin{array}{l}\text { Leukocyte } \\
\text { ligand }\end{array}$ & $\begin{array}{l}\text { Endothelial } \\
\text { ligand }\end{array}$ & Functions \\
\hline E-selectin & $\begin{array}{l}\text { PSGL-1, CD44, } \\
\text { ESL-1 }\end{array}$ & None & $\begin{array}{l}\text { Capturing, rolling, } \\
\text { integrin activation }\end{array}$ \\
\hline P-selectin & PSGL-1 & None & $\begin{array}{l}\text { Capturing, rolling, } \\
\text { integrin activation }\end{array}$ \\
\hline ICAM-1 & LFA-1, Mac-1 & None & $\begin{array}{l}\text { Rolling, adhesion, } \\
\text { crawling }\end{array}$ \\
\hline VCAM-1 & VLA4 & None & $\begin{array}{l}\text { Rolling, adhesion, } \\
\text { crawling }\end{array}$ \\
\hline RAGE & Mac-1 & None & $\begin{array}{l}\text { Adhesion, crawling, } \\
\text { transmigration }\end{array}$ \\
\hline ICAM-2 & LFA-1, Mac-1 & None & $\begin{array}{l}\text { Crawling, initiating } \\
\text { diapedesis }\end{array}$ \\
\hline JAM-A & LFA-1 & JAM-A & $\begin{array}{l}\text { Leukocyte } \\
\text { diapedesis }\end{array}$ \\
\hline JAM-B & VLA-4 & JAM-B, JAM-C & $\begin{array}{l}\text { Prevention of } \\
\text { reverse TEM }\end{array}$ \\
\hline JAM-C & Mac-1 & JAM-C, JAM-B & $\begin{array}{l}\text { Prevention of } \\
\text { reverse TEM }\end{array}$ \\
\hline ESAM & Unknown & ESAM & Diapedesis \\
\hline PECAM-1 & PECAM-1 & PECAM-1 & Promoting TEM \\
\hline CD99 & CD99 & CD99 & Promoting TEM \\
\hline CD99L2 & CD99L2 & CD99L2 & Promoting TEM \\
\hline VE-cadherin & None & VE-cadherin & $\begin{array}{l}\text { Preventing } \\
\text { diapedesis }\end{array}$ \\
\hline
\end{tabular}

Location and function of key leukocyte adhesion molecules and their ligands $[15,25,48]$

ESAM endothelial cell-selective adhesion molecule, CD99L2 CD99 antigen-like protein 2, JAM junctional adhesion molecule, PECAM-1 platelet endothelial cell adhesion molecule 1, VE-cadherin vascular endothelial cadherin, VLA4 very late antigen 4, TEM transendothelial migration

stage [26-28]. Expression profiles of the most relevant leukocyte adhesion molecules during fetal life is compared to that of adults in Table 2 and also depicted in Fig. 1 by respective footnotes.

Sperandio et al. showed in vivo that neutrophil rolling and adhesion in murine yolk sac vessels is strongly reduced at early gestational ages and increases throughout gestation [29]. These observations were validated in human preterm and term leukocytes in vitro using flow chamber experiments as a rule-in/rule-out approach [30]. In the same experimental setting, it has been shown that RAGE, a key metabolic receptor of diabetic patients, controls neutrophil adhesion in preterm and term infants [30].

Postnatal maturation of immune response and leukocyte recruitment is driven by multiple new environmental factors [31]. Several studies describe significantly reduced neutrophil transmigration and chemotaxis in neonates compared to adults $[11,29,32]$. Notably, cellular immunity of preterm infants matures slower and later than in term infants [11]. Expression of L-, P-, and E-selectin was reported to be reduced in mature neonates in vitro and in
Table 2 Expression of leukocyte adhesion molecules in neonates and adults

\begin{tabular}{|c|c|c|c|}
\hline \multirow{2}{*}{$\begin{array}{l}\text { Molecule } \\
\text { Mac-1 }\end{array}$} & \multirow{2}{*}{$\begin{array}{l}\text { Cell type } \\
\text { PMN }\end{array}$} & \multicolumn{2}{|c|}{$\begin{array}{l}\text { Expression in fetuses/premature } \\
\text { neonates compared to adults } \\
\text { and respective references }\end{array}$} \\
\hline & & $\begin{array}{l}\downarrow \text { Reduced } \\
\uparrow \text { Increased } \\
\leftrightarrow \text { Equal }\end{array}$ & $\begin{array}{l}{[26,31,36]} \\
{[37]} \\
{[30,33]}\end{array}$ \\
\hline LFA-1 & PMN & $\begin{array}{l}\downarrow \text { Reduced } \\
\leftrightarrow \text { Equal }\end{array}$ & $\begin{array}{l}{[26,45]} \\
{[30,31,36,37]}\end{array}$ \\
\hline CXCR2 & PMN & $\leftrightarrow$ Equal & [31] \\
\hline CD 18 & PMN & $\downarrow$ Reduced & {$[26]$} \\
\hline L-selectin & PMN & $\begin{array}{l}\downarrow \text { Reduced } \\
\leftrightarrow \text { Equal }\end{array}$ & $\begin{array}{l}{[26,33,37,45,46]} \\
{[47]}\end{array}$ \\
\hline E-selectin & $\begin{array}{l}\text { Skin } \\
\text { EC } \\
\text { Yolk sac vessels }\end{array}$ & $\begin{array}{l}\downarrow \text { Reduced } \\
\downarrow \text { Reduced } \\
\downarrow \text { Reduced }\end{array}$ & $\begin{array}{l}{[38]} \\
{[31]} \\
{[29]}\end{array}$ \\
\hline P-selectin & $\begin{array}{l}\text { EC } \\
\text { Fetal skin } \\
\text { PMN } \\
\text { Yolk sac vessels }\end{array}$ & $\begin{array}{l}\downarrow \text { Reduced } \\
\downarrow \text { Reduced } \\
\downarrow \text { Reduced } \\
\downarrow \text { Reduced }\end{array}$ & $\begin{array}{l}{[34]} \\
{[38]} \\
{[39]} \\
{[29]}\end{array}$ \\
\hline RAGE & PMN & $\uparrow$ Increased & [30] \\
\hline ICAM-1 & $\begin{array}{l}\text { Skin } \\
\text { EC } \\
\text { Yolk sac vessels }\end{array}$ & $\begin{array}{l}\downarrow \text { Reduced } \\
\downarrow \text { Reduced } \\
\downarrow \text { Reduced }\end{array}$ & $\begin{array}{l}{[38]} \\
{[31]} \\
{[29]}\end{array}$ \\
\hline ICAM-2 & Yolk sac vessels & $\downarrow$ Reduced & [29] \\
\hline VCAM-1 & $\begin{array}{l}\text { Skin } \\
\text { Yolk sac vessels }\end{array}$ & $\begin{array}{l}\downarrow \text { Reduced } \\
\downarrow \text { Reduced }\end{array}$ & $\begin{array}{l}{[38]} \\
{[29]}\end{array}$ \\
\hline PSGL-1 & $\begin{array}{l}\text { PMN } \\
\text { Yolk sac vessels }\end{array}$ & $\begin{array}{l}\downarrow \text { Reduced } \\
\downarrow \text { Reduced }\end{array}$ & $\begin{array}{l}{[31,39]} \\
{[29]}\end{array}$ \\
\hline PECAM-1 & $\begin{array}{l}\text { EC } \\
\text { Yolk sac vessels }\end{array}$ & $\begin{array}{l}\leftrightarrow \text { Equal } \\
\leftrightarrow \text { Equal }\end{array}$ & $\begin{array}{l}{[31]} \\
{[29]}\end{array}$ \\
\hline VE-cadherin & EC & $\leftrightarrow$ Equal & [31] \\
\hline VLA-4 & PMN & $\downarrow$ Reduced & [45] \\
\hline
\end{tabular}

PECAM-1 platelet endothelial cell adhesion molecule 1, VE-cadherin vascular endothelial cadherin, VLA4 very late antigen 4, EC endothelial cells

vivo compared to infants and adults [31, 33, 34]. On the other hand, posttranslational glycosylation of selectin ligands is augmented during the neonatal period [35]. In most studies, fetal expression of integrins such as Mac-1 and LFA-1 were described to be reduced or equal compared to adults [26, 30, 31, 33, 36, 37]. Similar observations have been described for other adhesion molecules such as ICAM-1/-2, VCAM-1, VLA4, and PSGL-1 [29, 31, 38, 39]. Although fetal expression of the majority of adhesion molecules is low when compared to term infants and adults [11, 26, 36], others, like CXCR2, PECAM-1, and VE-cadherin (and LFA-1), are equally expressed in premature and mature neonates and adults (Table 2) [29, 31, 37].

Taken together, the gestational age-dependent upregulation of adhesion molecules leads to functional maturation of leukocyte rolling, adhesion, transmigration, and chemotaxis, which in turn strengthens the innate immune response. 


\section{Analytical limitations and outlook}

Despite technical progress, human neonatal in vivo imaging of immune cell trafficking is not yet available. Thus, fetal leukocyte recruitment has mainly been studied in vitro using leukocytes and endothelial cells in dynamic flow chambers or transmigration assays $[15,30$, $31,40,41]$. Reports about in vivo investigations of fetal leukocyte recruitment in animals are limited and were mostly performed in nonmammalian organisms [42, 43]. A recently, developed intravital microscopic mouse model now offers the chance to visualize rolling and adhesive behavior of leukocytes during different stages of fetal development (E13-18) in vivo [29]. However, its microsurgery and microscopic approach is technically challenging and introduction of clinically relevant conditions difficult (Hudalla et al. in preparation). Moreover, the exploration of underlying mechanisms is often limited by sample sizes $[5,23,24]$.

While our understanding of the fetal and early neonatal immune system is ever growing, treatment options are still limited and the vast majority of pharmaceutical trials are run in adults with fully developed immunity. Novel analytical tools and models to study innate immunity may facilitate the development of new gestational age- and sepsis stage-specific therapeutic approaches to fine-tune the premature immune system and thereby optimize the treatment of neonatal infections and sepsis [44].

\begin{abstract}
Abbreviations
CD99L2: CD99 antigen-like protein 2; EC: Endothelial cell; ER: Endoplasmic reticulum; ESAM: Endothelial cell-selective adhesion molecule; ESL1: Eselectin ligand 1; fMLP: N-Formylmethionyl-leucyl-phenylalanine;

ICAM: Intercellular adhesion molecule; JAM: Junctional adhesion molecule; LFA-1: Lymphocyte function-associated antigen 1; LPS: Lipopolysaccharide; Mac-1: Macrophage antigen 1; PECAM-1: Platelet endothelial cell adhesion molecule 1; PMN: Polymorphonuclear neutrophils; PSGL-1: P-selectin glycoprotein ligand 1; RAGE: Receptor for advanced glycation endproducts; rtPCR: Real-time polymerase chain reaction; TEM: Transendothelial migration; VAP1: Vascular adhesion protein 1; VCAM-1: Vascular cell adhesion molecule 1; VE-cadherin: Vascular endothelial cadherin; VLA4: Very late antigen 4
\end{abstract}

\section{Acknowledgements}

This work was partially supported by DFG grant to DF (FR 3068/4-1).

\section{Competing interests}

The authors declare that they have no competing interests.

\section{Authors' contributions}

$\mathrm{KK}$ reviewed the literature and wrote the manuscript. $\mathrm{HH}$ co-wrote and edited the manuscript. DF supervised and contributed to the manuscript writing. All authors read and approved the final manuscript.

\section{Author details}

'Department of Neonatology, University Children's Hospital, Im Neuenheimer Feld 430, 69120 Heidelberg, Germany. 'Department of Newborn Medicine, Brigham and Women's Hospital, Harvard Medical School, Boston, MA, USA.

Received: 31 March 2016 Accepted: 12 October 2016

Published online: 24 October 2016

\section{References}

1. Howson M, Kinney J, Lawn J (2012) Lawn March of Dimes, PMNCH, Save the Children, WHO. born too soon: the global action report on preterm birth. World Health Organization, Geneva, p 17

2. Cohen-Wolkowiez M, Moran C, Benjamin D, Cotten M, Clark R, Benjamin D Jr, Smith P (2009) Early and late onset sepsis in late preterm infants. Pediatr Infect Dis J 28:1052-1056

3. Lawn J, Wilczynska-Ketende K, Cousens S (2006) Estimating the causes of 4 million neonatal deaths in the year 2000. Int J Epidemiol 35:706-718

4. Stoll B, Hansen N, Bell E et al (2010) Neonatal outcomes of extremely preterm infants. From the NICHD Neonatal Research Network. Pediatr 126: 443-456

5. Lawn J, Kerber K, Enweronu-Laryea C, Cousens S (2010) 3.6 million neonatal deaths - what is progressing and what is not? Semin Perinatol 34:371-386

6. Marodi L (2006) Neonatal innate immunity to infectious agents. Infect Immun 74:1999-2006

7. Klebanoff M, Keim S (2011) Epidemiology: the changing face of preterm birth. Clin Perinatol 38:339-350

8. Berg T, Jensen J (2011) Simultaneous parasympathetic and sympathetic activation reveals altered autonomic control of heart rate, vascular tension, and epinephrine release in anesthetized hypertensive rats. Front Neurol 2:71

9. Olbrich H, Cremers C, Loges NT et al (2015) Loss-of-function GAS8 mutations cause primary ciliary dyskinesia and disrupt the nexin-dynein regulatory complex. Am J Hum Genet 97:546-554

10. Dowling DJ, Levy O (2014) Ontogeny of early life immunity. Trends Immunol 35:299-310

11. Carr R (2000) Neutrophil production and function in newborn infants. Br J Haematol 110:18-28

12. Ley K, Laudanna C, Cybulsky M, Nourshargh S (2007) Getting to the site of inflammation: the leukocyte adhesion cascade updated. Nat Rev Immunol 7: 678-689

13. Nourshargh S, Alon R (2014) Leukocyte migration into inflamed tissues. Immunity 41:694-707

14. Zarbock A, Ley K, Mcever R, Hidalgo A (2011) Leukocyte ligands for endothelial selectins: specialized glycoconjugates that mediate rolling and signaling under flow. Blood 118:6743-6751

15. Frommhold D, Kamphues A, Hepper I et al (2010) RAGE and ICAM-1 cooperate in mediating leukocyte recruitment during acute inflammation in vivo. Blood 116:841-849

16. Dixit N, Simon S (2012) Chemokines, selectins and intracellular calcium flux: temporal and spatial cues for leukocyte arrest. Front Immunol 3:188

17. Alon R, Dustin M (2007) Force as a facilitator of integrin conformational changes during leukocyte arrest on blood vessels and antigen-presenting cells. Immunity 26:17-27

18. Ley K (2014) Arrest chemokines. Front Immunol 5:1-2

19. Zarbock A, Ley K (2008) Mechanisms and consequences of neutrophil interaction with the endothelium. Am J Pathol 172:1-7

20. Phillipson M, Heit B, Colarusso P, Liu L, Ballantyne C, Kubes P (2006) Intraluminal crawling of neutrophils to emigration sites: a molecularly distinct process from adhesion in the recruitment cascade. J Exp Med 203:2569-2575

21. Shulman Z, Shinder V, Klein E et al (2009) Lymphocyte crawling and transendothelial migration require chemokine triggering of high-affinity LFA-1 integrin. Immunity 30:384-396

22. Mcdonald B, Pittman K, Menezes G et al (2010) Intravascular danger signals guide neutrophils to sites of sterile inflammation. Science 330:362-366

23. Williams M, Azcutia V, Newton G, Alcaide P, Luscinskas F (2011) Emerging mechanisms of neutrophil recruitment across endothelium. Trends Immunol 32:461-469

24. Kunkel EJ, Dunne JL, Ley K (2000) Leukocyte arrest during cytokinedependent inflammation in vivo. Immunology 164:3301-3308

25. Vestweber D (2015) How leukocytes cross the vascular endothelium. Nat Rev Immunol 15:692-704

26. Strunk T, Temming P, Gembruch U, Reiss I, Bucsky P, Schultz C (2004) Differential maturation of the innate immune response in human fetuses. Pediatr Res 56:219-226

27. Naik-Mathuria B, Gay AN, Zhu X, Yu L, Cass DL, Olutoye OO (2007) Agedependent recruitment of neutrophils by fetal endothelial cells: implications in scarless wound healing. J Pediatr Surg 42:166-171

28. Olutoye OO, Zhu X, Cass DL, Smith CW (2005) Neutrophil recruitment by fetal porcine endothelial cells: implications in scarless fetal wound healing. Pediatr Res 58:1290-1294 
29. Sperandio M, Quackenbush E, Sushkova N et al (2013) Ontogenetic regulation of leukocyte recruitment in mouse yolk sac vessels. Blood 121: e118-e128

30. Buschmann K, Tschada R, Metzger M-S, Braach N, Kuss N, Hudalla H, Poeschl J, Frommhold D (2014) RAGE controls leukocyte adhesion in preterm and term infants. BMC Immunol 15:1471-2172

31. Nussbaum C, Gloning A, Pruenster M et al (2013) Neutrophil and endothelial adhesive function during human fetal ontogeny. J Leukoc Biol 93:175-184

32. Fox S, Lu W, Maheshwari A, Christensen R, Calhoun D (2005) The effects and comparative differences of neutrophil specific chemokines on neutrophil chemotaxis of the neonate. Cytokine 29:135-140

33. Moriguchi N, Yamamoto S, Isokawa S, Andou A, Miyata H (2006) Granulocyte functions and changes in ability with age in newborns; report no. 1: flow cytometric analysis of granulocyte functions in whole blood. Pediatr Int 48:17-21

34. Lorant D, Li W, Tabatabaei N, Garver M, Albertine K (1999) P-selectin expression by endothelial cells is decreased in neonatal rats and human premature infants. Blood 94:600-609

35. Hidalgo A, Frenette P (2005) Enforced fucosylation of neonatal CD34+ cells generates selectin ligands that enhance the initial interactions with microvessels but not homing to bone marrow. Blood 105:567-575

36. Storm S, Mariscalco M, Tosi M (2008) Postnatal maturation of total cell content and up-regulated surface expression of Mac-1 (CD11b/CD18) in polymorphonuclear leukocytes of human infants. J Leukoc Biol 84:477-479

37. Rebuck N, Gibson A, Finn A (1995) Neutrophil adhesion molecules in term and premature infants: normal or enhanced leucocyte integrins but defective L-selectin expression and shedding. Clin Exp Immunol 101:183-189

38. Davies JR, Dyson M, Mustafa Y, Compton F, Perry ME (1996) The ontogeny of adhesion molecules expressed on the vascular endothelium of the developing human skin. J Anat 189:373-382

39. Tcharmtchi MH, Smith CW, Mariscalco MM (2000) Neonatal neutrophil interaction with P-selectin: contribution of P-selectin glycoprotein ligand-1 and sialic acid. J Leukoc Biol 67:73-80

40. Frommhold D, Ludwig A, Bixel MG et al (2008) Sialyltransferase ST3Gal-IV controls CXCR2-mediated firm leukocyte arrest during inflammation. J Exp Med 205:1435-1446

41. Buschmann K, Koch L, Braach N, Mueller H, Frommhold D, Poeschl J, Ruef P (2012) CXCL1-triggered interaction of LFA1 and ICAM1 control glucoseinduced leukocyte recruitment during inflammation in vivo. Mediators Inflamm 2012:739176

42. Le Guyader D, Redd MJ, Colucci-Guyon E et al (2008) Origins and unconventional behavior of neutrophils in developing zebrafish. Blood 111: 132-141

43. Pase L, Nowell CJ, Lieschke GJ (2012) In vivo real-time visualization of leukocytes and intracellular hydrogen peroxide levels during a zebrafish acute inflammation assay. Methods Enzymol 506:135-156

44. Zhao J, Kim K, Yang X, Auh S, Fu Y, Tang H (2008) Hyper innate responses in neonates lead to increased morbidity and mortality after infection. Proc Natl Acad Sci U S A 105:7528-7533

45. Surbek DV, Steinmann C, Bürk M, Hahn S, Tichelli A, Holzgreve W (2000) Developmental changes in adhesion molecule expressions in umbilical cord blood CD34+ hematopoietic progenitor and stem cells. Am J Obstet Gynecol 183:1152-1157

46. Mariscalco M, Tcharmtchi MH, Smith C (1998) P-selectin support of neonatal neutrophil adherence under flow-contribution of L-selectin, LFA-1, and ligand(s) for P-selectin. Blood 91:4776-4785

47. Smith JB, Tabsh KM (1993) Fetal neutrophils and eosinophils express normal levels of $\mathrm{L}$ selectin. Pediatr Res 34:253-257

48. Muller W (2011) Mechanisms of leukocyte transendothelial migration. Annu Rev Pathol 6:323-344

\section{Submit your manuscript to a SpringerOpen ${ }^{\circ}$ journal and benefit from:}

- Convenient online submission

- Rigorous peer review

- Immediate publication on acceptance

- Open access: articles freely available online

- High visibility within the field

- Retaining the copyright to your article

Submit your next manuscript at $\gg$ springeropen.com 